\title{
Water Loss: A Nondestructive Indicator of Enhanced Cell Membrane Permeability of Chilling- injured Citrus Fruit
}

\author{
E. Cohen, B. Shapiro, Y. Shalom, and J.D. Klein \\ Department of Postharvest Science of Fresh Produce, Agricultural Research Organization, The Volcani \\ Center, Bet Dagan 50250, Israel
}

Additional index words. postharvest, electrical conductivity, ion leakage, $\mathrm{K}^{+}, \mathrm{Ca}^{2+}$, intermittent warming, grapefruit, lemon, shelf life

\begin{abstract}
Water loss was found to be a nondestructive indicator before visible symptoms of chilling injury (CI) in coldstored grapefruit (Citrus paradisi Macf.) and lemon (C. limon L. Burm. f.). The water-loss rate increased significantly after removing the fruit from cold storage and holding at $20 \mathrm{C}$. Scanning electron microscopy revealed large cracks around the stomata. Changes in electrical conductivity of the flavedo tissues, total electrolyte leakage, and $\mathrm{K}^{+}$or $\mathrm{Ca}^{2+}$ leakage were all inadequate predictors of CI, appearing only after CI was evident.
\end{abstract}

Chilling injury (CI) of citrus fruit is characterized by localized discoloration of the peel followed by the collapse of the affected area, which results in depressions on the fruit surface. Lyons (1973) suggested that CI is the result of ultrastructural membrane changes that permit electrolyte leakage and ion imbalance in the cell.

The increase in total ion leakage, $\mathrm{K}^{+}$leakage specifically, was reported to be a sensitive indicator of $\mathrm{CI}$ in grapefruit callus tissue (Forney and Peterson, 1990) and in whole oranges, limes, and grapefruit (Pantastico et al., 1968).

Since ion leakage measurements are, by their nature, destructive and time consuming, an indicator of CI was sought that would be relatively rapid, reliable, and nondestructive. We therefore investigated whether water loss could serve as a reliable nondestructive indicator of CI in stored grapefruit and lemons. These measurements were then compared with those for total electrolyte leakage, $\mathrm{K}^{+}$and $\mathrm{Ca}^{2+}$ leakage, specifically.

\section{Materials and Methods}

'Marsh' grapefruit and 'Villa franca' lemons were harvested and, without any treatment, divided into three lots, each consisting of three cartons with 50 grapefruit or 100 lemons each. One lot was stored at $2 \mathrm{C}$ (a CI-inducing temperature), the second lot was stored at $13 \mathrm{C}$ (a nonchilling temperature), and the third lot was stored under an intermittent warming (IW) regime of 21 days at $2 \mathrm{C}$ followed by 7 days at 13C (Cohen et al., 1983) for 12 weeks. Relative humidity was maintained at $\approx 90 \%$ under all storage conditions.

Weight loss was determined by individually weighing 15 grapefruit or 25 lemons per treatment at harvest and at 4-week intervals during storage. Fruit were also weighed daily during the 4 days of holding at 20C after removal from storage.

Electrical conductivity (EC) was measured using stainlesssteel electrodes, $5 \mathrm{~mm}$ apart, embedded in a rubber stopper and protruding $2 \mathrm{~mm}$. EC was measured at five locations along the equator of three randomly chosen washed fruit in each treatment.

Received for publication 2 Sept. 1993. Accepted for publication 18 Jan. 1994. Contribution no. 1166-E, 1993 series, from the Agricultural Research Organization, The Volcani Center, Bet Dagan, Israel. The cost of publishing this paper was defrayed in part by the payment of page charges. Under postal regulations, this paper therefore must be hereby marked advertisement solely to indicate this fact.
Membrane leakage was determined using fruit disks used for EC measurements. Five disks ( $10 \mathrm{~mm}$ in diameter, $3 \mathrm{~mm}$ thick) consisting of flavedo and albedo tissue were removed from each fruit and immersed in $15 \mathrm{ml}$ deionized water at $20 \mathrm{C}$ with constant shaking. After $3 \mathrm{~h}$ of incubation, the electrolyte reading of the bathing solution was measured using a conductivity meter (model LF 535; Wissenschiftlich TechnischeWerkstatten GmbH, Germany). The $\mathrm{K}^{+}$and $\mathrm{Ca}^{2+}$ contents of the bathing solution were measured using ion-specific electrodes. The tissues and solutions were then held at $-18 \mathrm{C}$ overnight followed by autoclaving (130C) for $15 \mathrm{~min}$ to permit complete leakage from the membranes. Percent leakage of total electrolytes, $\mathrm{K}^{+}$, and $\mathrm{Ca}^{2+}$ was calculated as the ratio of the initial reading to the final reading.

CI was quantified by assessing the surface area and depth of pitting that developed on the peel. Light, moderate, and severe pitting were rated as 1,2 , and 3, respectively, and the CI index was calculated by the formula [(no. of fruit ranked $1 \times 1)+($ no. of fruit ranked $2 \times 2)+($ no. of fruit ranked $3 \times 3)] /$ total number of fruit.

Scanning electron microscope (SEM) photographs from pitted and nonaffected disks of grapefruit peel were examined. Fruit were sampled after 3 months at 2C, with and without IW. Disks (4 mm) were critical-point dried after fixation in glutaraldehyde followed by osmium tetroxide and then serially dehydrated in ethanol. The samples were attached to the microscope stub, coated with gold, and observed at 10 to $15 \mathrm{kV}, 0^{\circ}$ tilt angle, and $15-\mathrm{mm}$ working distance. External morphology of epidermal cell and wax structure was studied in a wide range of magnification: $\times 50$ to $\times 15,000$.

\section{Results}

Weight loss increased during storage, regardless of temperature. However, weight loss was greater in grapefruit (Fig. 1) and lemon (Fig. 2) held at $13 \mathrm{C}$ than at $2 \mathrm{C}$, with or without IW. Lemons lost more weight than grapefruit (12\% vs. 5.8\% after 12 weeks at 13C). After removal to $20 \mathrm{C}$, the fruit that had been held at $2 \mathrm{C}$ lost more additional weight than those that had been held at $13 \mathrm{C}$. However, weight loss from fruit that had undergone IW during 2C storage was similar to that of fruit from 13C.

$\mathrm{EC}$ in the flavedo was lower and electrolyte leakage (total, $\mathrm{K}^{+}$, or $\mathrm{Ca}^{2+}$ ) was generally higher in grapefruit than in lemon (Table 1). In flavedo tissue with no visible signs of $\mathrm{CI}$, there were minor significant effects between storage temperatures on EC or leakage during storage. More consistent effects were found after fruit were 


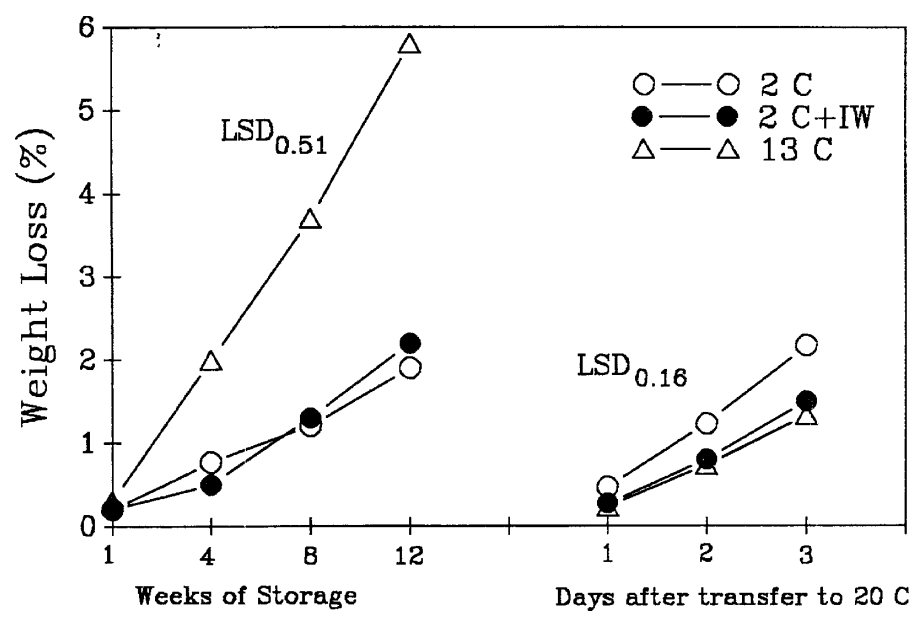

Fig. 1. Percent weight loss in grapefruit during storage under different temperature regimes and after transfer to $20 \mathrm{C}$. IW= intermittent warming.

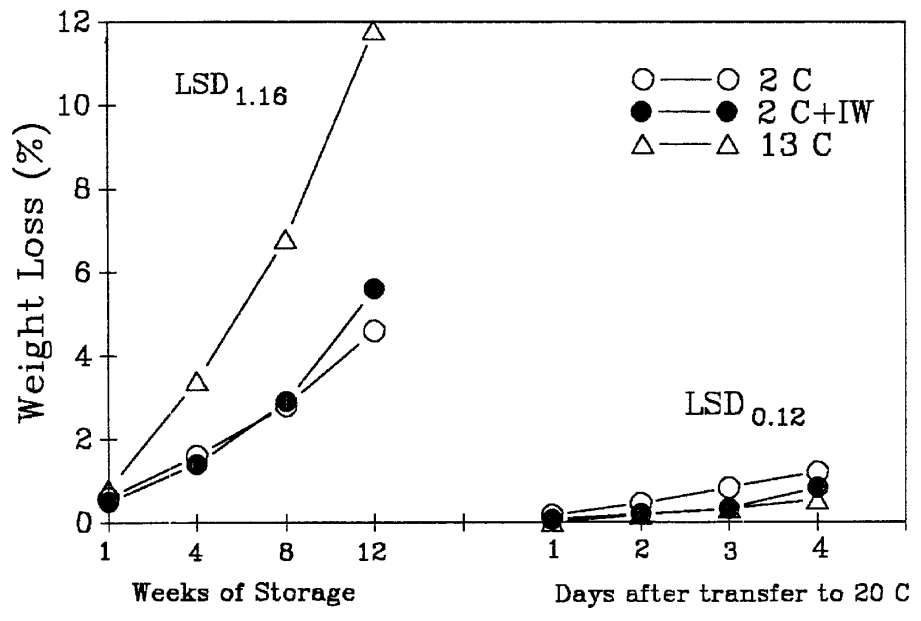

Fig. 2. Percent weight loss in lemon fruit during storage under different temperatures regimes and after transfer to $20 \mathrm{C}$. IW= intermittent warming.

Table 1. Electrical conductivity (EC) and percent leakage during storage and after transfer to 20C.

\begin{tabular}{|c|c|c|c|c|c|c|c|c|c|}
\hline \multirow[b]{3}{*}{ Treatment $^{2}$} & \multicolumn{4}{|c|}{ Grapefruit } & \multicolumn{5}{|c|}{ Lemon } \\
\hline & \multicolumn{3}{|c|}{ Weeks of storage } & \multirow{2}{*}{$\begin{array}{l}+3 \text { days } \\
\text { at } 20 \mathrm{C}\end{array}$} & \multicolumn{4}{|c|}{ Weeks of storage } & \multirow{2}{*}{$\begin{array}{l}+4 \text { days } \\
\text { at } 20 \mathrm{C}\end{array}$} \\
\hline & 1 & 4 & 8 & & 1 & 4 & 8 & 12 & \\
\hline \multicolumn{10}{|c|}{ EC flavedo ( $\mu$ mhos) } \\
\hline $13 \mathrm{C}$ & $12.9 \mathrm{a}^{\mathrm{y}}$ & $12.5 \mathrm{a}$ & $12.8 \mathrm{~b}$ & $18.1 \mathrm{~b}$ & $14.6 \mathrm{a}$ & $15.5 \mathrm{a}$ & $15.4 \mathrm{c}$ & $17.7 \mathrm{a}$ & $18.1 \mathrm{a}$ \\
\hline $2 \mathrm{C}$ & $10.2 \mathrm{~b}$ & $12.4 \mathrm{a}$ & $12.6 \mathrm{~b}$ & $19.0 \mathrm{a}$ & $14.1 \mathrm{a}$ & $14.2 \mathrm{~b}$ & $13.1 \mathrm{~b}$ & $17.7 \mathrm{a}$ & $22.0 \mathrm{a}$ \\
\hline $2 \mathrm{C}+\mathrm{IW}$ & $10.2 \mathrm{~b}$ & $11.9 \mathrm{a}$ & $14.8 \mathrm{a}$ & $19.4 \mathrm{a}$ & $14.1 \mathrm{a}$ & $16.1 \mathrm{a}$ & $17.9 \mathrm{a}$ & $19.0 \mathrm{a}$ & $21.3 \mathrm{a}$ \\
\hline \multicolumn{10}{|c|}{ Electrolyte leakage $(\%)$} \\
\hline $13 \mathrm{C}$ & $25.3 \mathrm{~b}$ & $29.3 \mathrm{a}$ & $21.3 \mathrm{c}$ & $70.4 \mathrm{a}$ & $25.7 \mathrm{a}$ & $20.5 \mathrm{~b}$ & $12.5 \mathrm{~b}$ & $26.1 \mathrm{a}$ & $25.3 \mathrm{~b}$ \\
\hline $2 \mathrm{C}$ & $30.0 \mathrm{a}$ & $32.1 \mathrm{a}$ & $23.9 \mathrm{~b}$ & $60.4 \mathrm{~b}$ & $19.6 \mathrm{~b}$ & $26.6 \mathrm{~b}$ & $14.0 \mathrm{~b}$ & $21.7 \mathrm{~b}$ & $26.9 \mathrm{~b}$ \\
\hline $2 \mathrm{C}+\mathrm{IW}$ & $30.0 \mathrm{a}$ & $39.5 \mathrm{a}$ & $31.4 \mathrm{a}$ & $63.0 \mathrm{~b}$ & $19.6 \mathrm{~b}$ & $35.4 \mathrm{a}$ & $21.7 \mathrm{a}$ & $20.6 \mathrm{~b}$ & $32.3 \mathrm{a}$ \\
\hline \multicolumn{10}{|c|}{$K^{+}$leakage $(\%)$} \\
\hline $13 \mathrm{C}$ & $50.6 \mathrm{a}$ & $71.2 \mathrm{a}$ & $38.5 \mathrm{a}$ & $48.5 \mathrm{~b}$ & $49.3 \mathrm{a}$ & $58.1 \mathrm{a}$ & $30.9 \mathrm{a}$ & $46.4 \mathrm{a}$ & $51.6 \mathrm{~b}$ \\
\hline $2 \mathrm{C}$ & $54.0 \mathrm{a}$ & $72.0 \mathrm{a}$ & $44.0 \mathrm{a}$ & $44.3 \mathrm{c}$ & $30.7 \mathrm{~b}$ & $52.9 \mathrm{a}$ & $30.6 \mathrm{a}$ & $38.7 \mathrm{~b}$ & $60.2 \mathrm{a}$ \\
\hline $2 \mathrm{C}+\mathrm{IW}$ & $54.0 \mathrm{a}$ & $68.2 \mathrm{a}$ & $37.7 \mathrm{~b}$ & $53.7 \mathrm{a}$ & $30.7 \mathrm{~b}$ & $52.9 \mathrm{a}$ & $30.6 \mathrm{a}$ & $38.7 \mathrm{~b}$ & $48.9 \mathrm{ab}$ \\
\hline \multicolumn{10}{|c|}{$\mathrm{Ca}^{2+}$ leakage $(\%)$} \\
\hline $13 \mathrm{C}$ & $81.9 \mathrm{a}$ & $92.5 \mathrm{a}$ & $57.7 \mathrm{a}$ & $73.6 \mathrm{~b}$ & $75.2 \mathrm{a}$ & $91.1 \mathrm{a}$ & $42.4 \mathrm{a}$ & $84.3 \mathrm{a}$ & $51.0 \mathrm{a}$ \\
\hline $2 \mathrm{C}$ & $100.0 \mathrm{a}$ & $86.5 \mathrm{a}$ & $68.1 \mathrm{a}$ & $68.1 \mathrm{~b}$ & $89.1 \mathrm{a}$ & $93.1 \mathrm{a}$ & $48.8 \mathrm{a}$ & $85.8 \mathrm{a}$ & $77.0 \mathrm{a}$ \\
\hline $2 \mathrm{C}+\mathrm{IW}$ & $100.0 \mathrm{a}$ & $93.1 \mathrm{a}$ & $63.4 \mathrm{a}$ & $86.1 \mathrm{a}$ & $89.1 \mathrm{a}$ & $83.6 \mathrm{a}$ & $41.4 \mathrm{a}$ & $67.2 \mathrm{a}$ & $56.4 \mathrm{a}$ \\
\hline
\end{tabular}

${ }^{\mathrm{z}} \mathrm{IW}=$ intermittent warming.

yMean separation within columns nonsignificantly different at $P=0.05$ according to Duncan's multiple range test.

transferred to 20C (Table 1). However, EC was significantly greater in CI-affected (pitted) tissue (24.2 and $30.9 \mu$ mhos in grapefruit and lemon, respectively) than in sound tissue (18.1 and $24.1 \mu \mathrm{mhos}$ in grapefruit and lemon, respectively; data not shown).

The injury index in grapefruit stored at $2 \mathrm{C}$ was 1.1 after 6 weeks of storage, increasing to 2.6 after 12 weeks. In lemon, there was no injury after 6 weeks, whereas the rating was 2.0 after 12 weeks. Fruit that were stored at $2 \mathrm{C}$ with IW had reduced injury indexes of 1.1 (grapefruit) and 0.5 (lemon) after 12 weeks of storage. No CI developed on fruit held at 13C. Epidermal cells from flavedo of CIdamaged (pitted) grapefruit stored at $2 \mathrm{C}$ showed distinctive swollen areas with depressions (Fig. 3A) and areas of cuticular damage of the usual wax layer (Fig. 3B). Furthermore, epidermal cells from the same fruit that had been stored at $2 \mathrm{C}$, but that did not yet have visible signs of CI, were revealed under SEM to be in different stages of microcollapse and cracking around the stomata (Fig. 3C), with calcium oxalate crystals growing inside the cracks (Fig. 3D). It was found that, in fruit stored at $2 \mathrm{C}$ with IW, the epidermal cells were complete, the stomata had no cracking around them (Fig. 3E), and the wax layer appeared uniformly smooth and porous (Fig. 3F).

\section{Discussion}

The decreased weight loss (water loss) in citrus fruit stored at $2 \mathrm{C}$ is probably due to the lower transpiration rate at that temperature compared with 13C. However, the water-loss rate increased dramatically once fruit were removed from 2 to 20C. McCollum (1989) also found that chilled squash fruit had a greater weight-loss rate after transfer to $15 \mathrm{C}$ than nonchilled fruit. We found in citrus fruit that this loss was associated with the development of microscopic cracking in otherwise sound-appearing peel tissue. Schiffmann-Nadel et al. (1980) hypothesized the existence of such cracks as an underlying cause for the development of mold in CIaffected citrus fruit. Cohen et al.(1988) made these cracks visible by dipping fruit in malachite green solution. The cuticle and outer epidermal cells of fruit that had been stored at $2 \mathrm{C}$, while appearing 

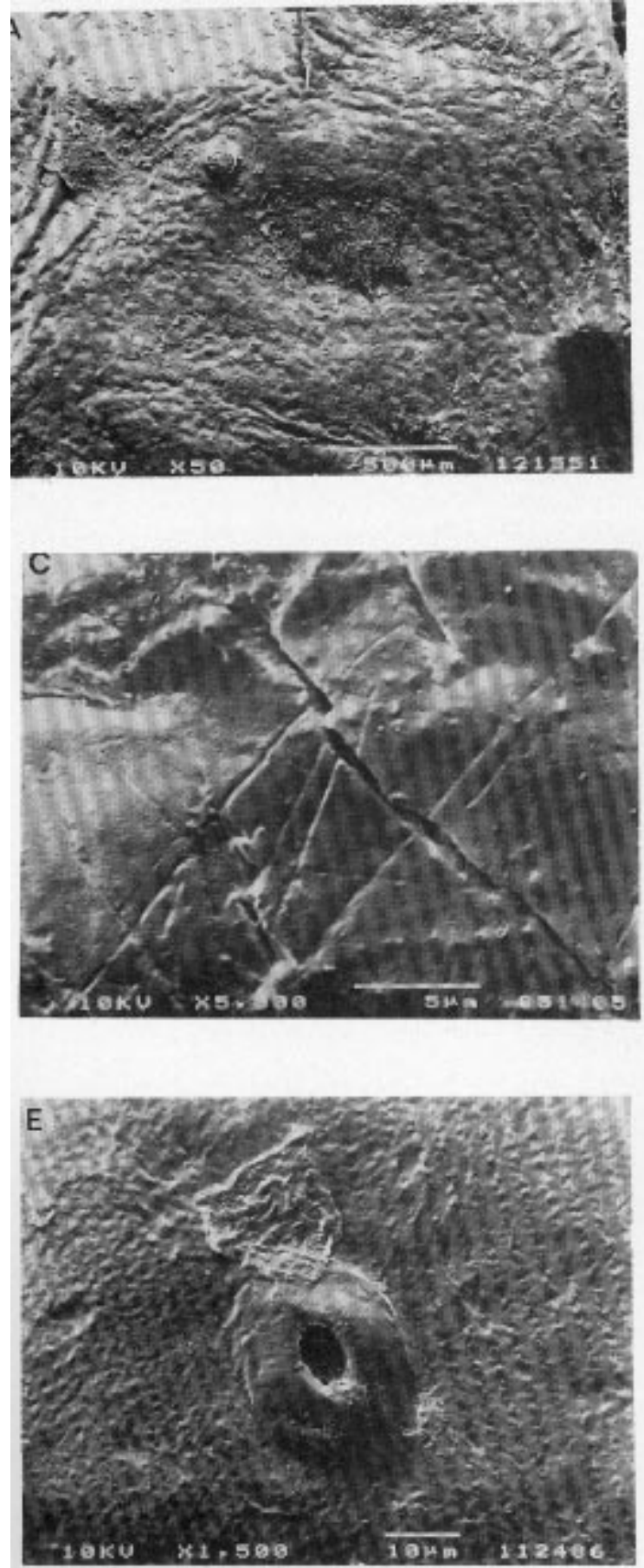
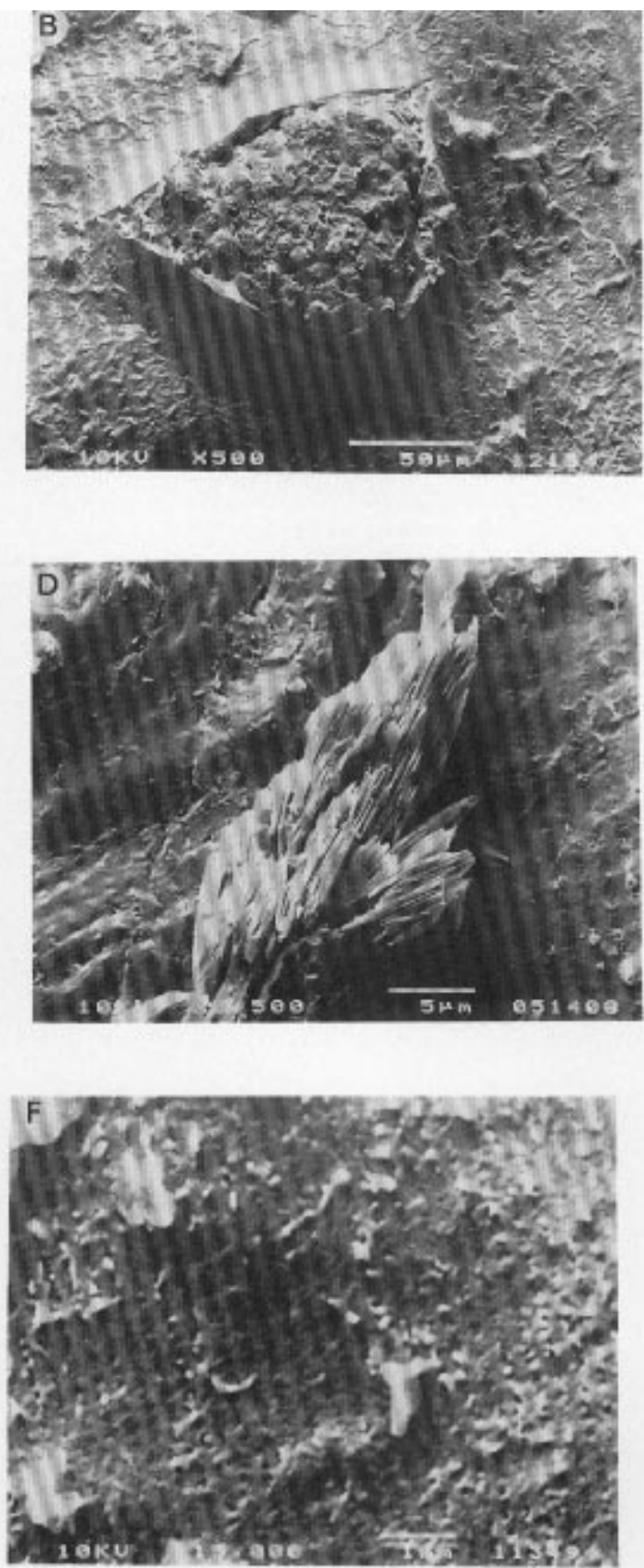

Fig. 3. Scanning electron microscopy of epidermal cells of grapefruit from chill-damaged (pitted) flavedo from fruit stored 3 months at 2C: (A) distinctive swollen areas, (B) greatly thinned wax layer. Fruit without visible damage stored at 2C: (C) cracking around stomata, (D) calcium oxalate crystals inside cracks. Fruit intermittently warmed during cold storage: (E) fruit surface healthy showing no cracking around stomata, (F) a smooth wax layer showing some wax structure.

sound, were revealed to be extensively injured. These fruit were easily infected by Penicillium digitatum, a wound parasite fungus that infects citrus fruit only through injuries. Our work shows that such cracks occur after exposure to chilling temperatures and are most likely sites for fungal infection.

CI symptoms can be reduced in some chilling-sensitive tissues by modifying the pattern of temperature exposure (Morris, 1982; Saltveit, 1991; Wang, 1982). IW is one such temperature modification that reduces CI in citrus (Cohen et al., 1983; Davis and Hofmann, 1973; Eaks, 1965). We report here that IW minimized water loss associated with low-temperature storage, probably by reducing the rate of cuticular cracking associated with CI. The decrease in water loss was more evident in lemon than in grapefruit, possibly because the IW formula used was developed specifically for lemon (Cohen et al., 1983). Water loss after removal from cold storage to $20 \mathrm{C}$ can serve as a nondestructive predictor of CI, since it was significantly $(P=0.05)$ correlated with $\mathrm{CI}$ index in grapefruit $(r=0.996)$ and lemon $(r=0.705)$.

EC and electrolyte leakage were of limited value as indicators of storage quality. Leakage increased in tissues that showed visible CI symptoms, which corresponds to the longer storage life of lemon. However, electrolyte leakage was not affected by storage 
temperature, which is the most significant causal factor in CI. Our results agree with those of McCollum and McDonald (1991) that leakage is an ineffective parameter of CI in citrus and support the contention of Whitlow et al. (1992) that membrane competence cannot be effectively measured using traditional calculations of ion leakage.

\section{Literature Cited}

Cohen, E., I. Rosenberger, and Y. Shalom. 1988. Effect of volatiles on the development of chilling injury in long-term storage of citrus fruits at suboptimal temperature. Israel Agr. 2:57-65.

Cohen, E., M. Shuali, and Y. Shalom. 1983. Effect of intermittent warming on the reduction of chilling injury of Villa Franca lemon fruits stored at cold temperature. J. Hort. Sci. 58:593-598.

Davis, P.L. and R.C. Hofmann. 1973. Reduction of chilling injury of citrus fruit in cold storage by intermittent warming. J. Food Sci. 38:871-873.

Eaks, I.L. 1965. Effect of chilling on the respiration of oranges and lemons. Proc. Amer. Soc. Hort. Sci. 87:181-186.

Forney, C.F. and S.J. Peterson. 1990. Chilling induced potassium leakage of cultured citrus cells. Physiol. Plant. 78:193-196.
Lyons, J.M. 1973. Chilling injury in plants. Annu. Rev. Plant Physiol. 24:445-466.

McCollum, T.G. 1989. Physiological changes in yellow summer squash at chilling and nonchilling temperatures. HortScience 24:633-635.

McCollum, T.G. and R.E. McDonald. 1991. Electrolyte leakage, respiration, and ethylene production as indices of chilling injury in grapefruit. HortScience 26:1191-1192.

Morris, L.L. 1982. Chilling injury of horticultural crops: An overview. HortScience 17:161-164.

Pantastico, E.B., J. Soule, and W. Grierson. 1968. Chilling injury in tropical and subtropical fruits: II. Limes and grapefruit. Proc. Trop. Region Amer. Soc. Hort. Sci. 12:171-183.

Saltveit, Jr., M.E. 1991. Prior temperature exposure affects subsequent chilling sensitivity. Physiol. Plant. 82:529-536.

Schiffmann-Nadel, M., E. Chalutz, and J. Waks. 1980. Relations between chilling injury and rot development in citrus fruit. Proc. 5th Congr. Mediterranean Phytopathol. Union (Patra, Greece). p. 119-120.

Wang, C.Y. 1982. Physiological and biochemical responses of plants to chilling stress. HortScience 17:173-186.

Whitlow, T.H., N.L. Bassuk, T.G. Ranney, and D.L. Reichert. 1992. An improved method for using electrolyte leakage to assess membrane competence in plant tissues. Plant Physiol. 98:198-205. 